\title{
Preparation of Titanium Dioxide Hollow Fiber Membrane Using Phase Inversion and Sintering Technique for Gas Separation and Water Purification
}

(Penyediaan Membran Gentian Geronggang Titanium Dioksida $\left(\mathrm{TiO}_{2}\right.$ ) Menggunakan Teknik Penyongsangan Fasa dan Persinteran untuk Pemisahan Gas dan Penulenan Air)

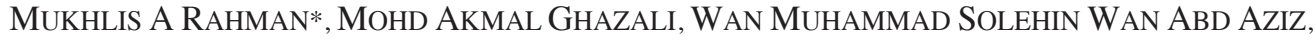 \\ MOHD HAFIZ DZARFAN OTHMAN, JUHANA JAAFAR \& AHMAD FAUZI ISMAIL
}

\begin{abstract}
This article describes the preparation of titanium dioxide $\left(\mathrm{TiO}_{2}\right)$ hollow fiber membrane using phase inversion and sintering technique. In this study, nano-sized $\mathrm{TiO}_{2}$ powders with different particle sizes were used to prepare ceramic hollow fiber membranes. In a series of preparation steps, a dispersant was dissolved in organic solvent before the addition of ceramic powders. These steps were followed by the addition of polymer binder. The membrane precursor was obtained by extruding the ceramic suspension into a coagulation bath, which enabled the precipitation of the precursor of ceramic hollow fiber membrane. The dried precursor was later sintered at temperatures ranging from 1200 to $1300^{\circ} \mathrm{C}$ to obtain $\mathrm{TiO}_{2}$ hollow fiber membrane. Scanning electron microscopy (SEM) was used to study the morphology of TiO hollow fiber membrane. The SEM images show the membrane can be shaped into asymmetric structure and symmetric structure based on the ceramic suspension compositions. The highest mechanical strength obtained was 223 MPa when the membrane prepared using $20 \mathrm{wt}$. \% ceramic loading of single nano-sized powder and sintered at $1300^{\circ} \mathrm{C} \mathrm{TiO}_{2}$ hollow fiber membrane prepared using similar ceramic loading showed high permeation rate of inert gas. High pure water fluxes were obtained when permeability tests was carried out using $\mathrm{TiO}_{2}$ hollow fiber membrane, prepared using mixture of nano-sized particles, even though its cross-section have a sponge-like structure.
\end{abstract}

Keywords: Nano-size particles; phase inversion; sintering process; titanium dioxide

\section{ABSTRAK}

Artikel ini menerangkan penyediaan membran gentian geronggang titanium dioksida ( $\mathrm{TiO}_{2}$ ) menggunakan teknik penyongsangan fasa dan persinteran. Partikel $\mathrm{TiO}_{2}$ bersaiz nano dengan saiz partikel yang berbeza telah digunakan untuk menyediakan membran seramik. Dalam langkah persediaan, bahan penyerak dilarutkan terlebih dahulu sebelum penambahan bahan seramik. Langkah ini diikuti dengan penambahan pengikat polimer. Pelopor membran telah diperoleh dengan menyemperit campuran seramik ke dalam takungan pengentalan, bagi membolehkan pemendakan pengikat polimer berlaku. Pelopor yang telah kering kemudiannya disinter pada julat suhu 1200 dan $1300^{\circ} \mathrm{C}$ untuk mendapatkan membran gentian geronggang $\mathrm{TiO}_{2}$. Mikroskop elektron imbasan (SEM) digunakan untuk mengkaji morfologi TiO gentian geronggang membran. Imej SEM menunjukkan membran boleh dibentuk menjadi struktur yang simetri dan struktur yang tidak simetri berdasarkan komposisi campuran seramik. Kekuatan mekanik tertinggi yang diperoleh ialah 223 MPa apabila membran disediakan dengan menggunakan $20 \%$ (berat) seramik (serbuk bersaiz nano tunggal) dan disinter pada suhu $1300^{\circ} \mathrm{C}$. Gentian geronggang membran $\mathrm{TiO}$ disediakan dengan menggunakan muatan seramik sama menunjukkan kadar ketelapan yang tinggi terhadap gas lengai. Kadar ketelapan air yang tinggi diperoleh apabila ujian kebolehtelapan dilakukan dengan menggunakan gentian geronggang membran $\mathrm{TiO}_{2}$, disediakan dengan menggunakan campuran partikel bersaiz nano, walaupun keratan rentas tersebut mempunyai struktur seperti span.

Kata kunci: Fasa balikan; partikel bersaiz nano; proses persinteran; titanium dioksia

\section{INTRODUCTION}

Membrane technology have been developed in the past decade to facilitate the separation process in various applications i.e. wastewater treatment, gas purification and fuel cell technology (Koros et al. 1992). The technique used to fabricate high performance membrane has also been established (Ulbricht 2006). The fabrication of membranes for various applications frequently used polymeric materials, which are easily available, cheap and easily fabricated (Shao \& Huang 2007). Various researchers have reported that these polymeric membranes have excellent performances in term of flux, rejection and selectivity, but the use of this technology is limited to the applications that operate under mild conditions i.e. at ambient temperature and pressure and under neutral pH (Zaidi 2003). To overcome the limitations faced by polymeric membrane, there is an increasingly interest to use ceramic membrane for 
applications under extreme conditions. In recent years, interests in the development of ceramic membrane for gas separation and water purification have increased due to its various advantageous compared to its polymeric counterpart. Ceramic membrane can be used at high temperature, under high pressure and in corrosive environment, making it more favourable to be used for large scale operation (Wu et al. 2012).

Typically, ceramic membranes have been prepared into asymmetric or composite type, which consists of a number of layers of one or more different ceramic materials (Wei et al. 2008). A support layer with acceptable mechanical strength is needed onto which an intermediate layer will be placed. This intermediate layer normally has narrow pore size distribution acts as middle layer between support layer and the thin ceramic membrane in which the actual separation takes place. The preparation of thin layer ceramic membrane can be accomplished using sol-gel method (Lange et al. 1995). Using this approach, multiple steps of casting should be carried out to obtain appropriate thickness of the membrane. However, the drawback of this technique is that the preparation steps are expensive and consume more energy.

Recently, single step preparation of ceramic membrane has been successfully discovered, which enables ceramic powder to be transformed into unsupported ceramic membrane either in hollow fiber or flat-sheet configurations (Kingsbury \& Li 2009). The technique that is known as the phase inversion and followed by sintering technique involves the preparation of ceramic suspension followed by a coagulation process in non-solvent bath. Controlled sintering process is used to change the dried precursor into ceramic membrane. Therefore, the main objective of this study was to prepare ceramic hollow fiber membrane from nano-size ceramic powders using this approach. Nano-sized titanium dioxide $\left(\mathrm{TiO}_{2}\right)$ with different particle sizes has been chosen as a ceramic material. The selection of nano-sized $\mathrm{TiO}_{2}$ particles as ceramic material has been made as it is rarely used as starting material in the preparation of ceramic membrane. Typically, organic-based precursors have been chosen to prepare supported $\mathrm{TiO}_{2}$ membrane using the sol-gel method. $\mathrm{TiO}_{2}$ hollow fiber membranes prepared were later characterized and their performances for water purification and gas separation were tested.

\section{MATERIALS AND METHODS}

\section{MATERIALS}

Titanium dioxide powders of 25 and $80 \mathrm{~nm}$ were purchased from Evonik GmbH and Qrec (Asia) Pvt. Ltd., respectively and were used as supplied. Polyethersulfone (Radal A300, Ameco Performance, USA), N-methyl-2-pyrrolidone (HPLC grade, Rathbone) and Arlacel P135 (Polyethyleneglycol 30-dipolyhydroxystearate, Uniqema) were used as binder, solvent and additive, respectively. Tap water and de-ionized water were used as the external and internal coagulants, respectively.

\section{PREPARATION OF $\mathrm{TIO}_{2}$ HOLLOW FIBER MEMBRANE}

Arlacel P135 was dissolved in N-methyl-2-pyrrolidone (NMP) prior to the addition of $\mathrm{TiO}_{2}$ powders. The dispersion was milled with $20 \mathrm{~mm}$ agate milling balls for $24 \mathrm{~h}$. Milling was continued for a further $24 \mathrm{~h}$ after the addition of PESf. The suspension was degassed to remove air bubble before being transferred into a stainless steel container. The spinning process was carried out by extruding the suspension through a spinneret into an external coagulant with an air gap of $15 \mathrm{~cm}$. De-ionized water was used as the internal coagulant. The extrusion rates of the suspension and the flow rate of the internal coagulant were accurately monitored and controlled by syringe pumps. $\mathrm{TiO}_{2}$ hollow fibre precursors were left in the external coagulation bath overnight to enable the completion of phase-inversion process before being cut and dried at room temperature. $\mathrm{TiO}_{2}$ hollow fibres were obtained at different sintering temperatures (1200 and $1300^{\circ} \mathrm{C}$ ) by sintering its precursor using an XY-1700 tubular furnace. The temperature was increased from room temperature to $600^{\circ} \mathrm{C}$ at a rate of $2^{\circ} \mathrm{C} \cdot \mathrm{min}^{-1}$ and held for $2 \mathrm{~h}$, then to $1000^{\circ} \mathrm{C}$ at a rate of $5^{\circ} \mathrm{C} \cdot \mathrm{min}^{-1}$ and held for 2 $\mathrm{h}$ and finally at a target temperature at a rate of $5^{\circ} \mathrm{C} \cdot \mathrm{min}^{-1}$ and held for $4 \mathrm{~h}$. The temperature was then reduced to room temperature at a rate of $5^{\circ} \mathrm{C} \cdot \mathrm{min}^{-1}$.

\section{CHARACTERIZATION}

The morphology of $\mathrm{TiO}_{2}$ hollow fibre substrates was observed using a scanning electron microscope (TM 3000, Hitachi). The SEM images of both the surface and crosssection were recorded at different magnifications. The mechanical strength of hollow fibres was examined by three-points bending test using Instron Model 5544 tensile tester provided with a load cell of $1 \mathrm{kN}$. Hollow fibres were fixed on the sample holder with a constant span length. The bending strength $(\sigma \mathrm{F})$ is calculated using (1) (Liu et al. 2001; Othman et al. 2010b):

$$
\sigma_{\mathrm{F}}=\frac{8 \mathrm{FLD}_{0}}{\pi\left(\mathrm{D}_{0}^{4}-\mathrm{D}_{1}^{4}\right)},
$$

where $\mathrm{F}$ is the measured maximum load at which the fracture occurred and $\mathrm{L}, \mathrm{D}_{\mathrm{o}}$, and $\mathrm{D}_{\mathrm{i}}$ are the length of span $(43 \mathrm{~mm})$, the outer diameter and the inner diameter of the hollow fibers, respectively. The permeation tests were carried out using helium gas to study the inert gas permeation across the membrane. The pure water flux of the $\mathrm{TiO}_{2}$ hollow fiber membranes was measured with a cross-flow filtration system using $15 \mathrm{~cm}$ length fibers. The apparatus was operated with a feed velocity of 3.0 $\mathrm{m} / \mathrm{s}$ and trans-membrane pressure difference of 1-2 bars. Before the measurements of permeate flux, all the samples were immersed in deionized water for $20 \mathrm{~min}$. All the measurements were conducted at room temperature. 


\section{RESULTS AND DISCUSSION}

\section{SPINNABILITY OF $\mathrm{TIO}_{2}$ HOLLOW FIBER MEMBRANE}

$\mathrm{TiO}_{2}$ hollow fiber membranes were fabricated using phase inversion and sintering technique using different particles sizes. The initial preparation of spinning suspension was formulated based on the composition imitated from previous study by Kingsbury and Li (2009). The ratio between ceramic particle and polymer binder was fixed at 10:1. For the suspension prepared using single particles size, which is $25 \mathrm{~nm}$, a weight loading of $20 \mathrm{wt}$. \% was chosen. This was based on 'try and error' approach in order to find a suitable range of ceramic loading for the preparation of ceramic suspension using single nano-size particle. The ceramic suspension obtained was extremely diluted and was unable to be solidified into solid precursor of ceramic hollow fiber membrane. It was expected that the content of polymer binder was insufficient to cover high surface area of nano-sized $\mathrm{TiO}_{2}$, causing dispersion of the ceramic particles in the coagulation bath. Similar phenomenon occurred to the suspension prepared using mixed nano-sized particles of 25 and $80 \mathrm{~nm}$ using the ratio of 10:1. However, when the ratio of ceramic and polymer binder was reduced, the preparation of $\mathrm{TiO}_{2}$ became stable and smooth, which enabled the precursor to be collected. Data in Table 1 shows single nano-sized particle of $25 \mathrm{~nm}$ required more polymer binder than mixture of particles.
The higher the surface area of ceramic particles, the higher the amount of polymer that was required as it was necessary to avoid water contact with ceramic during phase inversion.

The ceramic loading between ceramic suspensions also varied when different particle sizes of $\mathrm{TiO}_{2}$ were used. The single nano-sized powder required the ceramic loading to be reduced in the range of 20 to $23 \mathrm{wt}$. \%. Otherwise, the precursor will not form, either it was too dilute or too viscous. Using mixed nano-sized particles, the ceramic loading can be increased up to 43 to $45 \mathrm{wt}$. \%. Typically, it was desired to increase the weight loading of ceramic as it can contribute to the mechanical strength of ceramic hollow fiber membrane.

\section{MORPHOLOGY OF $\mathrm{TIO}_{2}$ HOLLOW FIBER MEMBRANE}

Typically, the morphology of ceramic hollow fiber membrane prepared using phase inversion is hard to predict as it influenced by various spinning conditions. The ceramic hollow fiber membrane prepared using this technique normally has a combination of finger-like structure and sponge-like structure in the inner region and outer region, respectively. However, the membrane cross-section may vary if various parameters were changed during spinning process. To study the effect of spinning conditions on morphology of $\mathrm{TiO}_{2}$ hollow fiber membrane, the ceramic suspension prepared from single nano-sized particle was spun at different air gap distances. As can be seen from Figure 1, the finger-like structure originated

TABLE 1. Spinning conditions for preparation of $\mathrm{TiO}_{2}$ hollow fiber membrane

\begin{tabular}{lccccc}
\hline Ceramic particles & $\begin{array}{c}\text { Ceramic/ } \\
\text { Polymer ratio }\end{array}$ & $\begin{array}{c}\text { Ceramic loading } \\
\text { (wt. \%) }\end{array}$ & $\begin{array}{c}\text { Air gap } \\
(\mathrm{cm})\end{array}$ & $\begin{array}{c}\text { Extrusion rate } \\
(\mathrm{mL} / \mathrm{min})\end{array}$ & $\begin{array}{c}\text { Bore fluid flow } \\
\text { rate }\end{array}$ \\
\hline $25 \mathrm{~nm}(100 \%)$ & $2: 1$ & 20 & 9 & 10 & 10 \\
$25 \mathrm{~nm}(100 \%)$ & $2: 1$ & 23 & 12 & 10 & 10 \\
$25 \mathrm{~nm} / 80 \mathrm{~nm}(30 \% / 70 \%)$ & $5: 1$ & 43 & 15 & 10 & 10 \\
$25 \mathrm{~nm} / 80 \mathrm{~nm}(30 \% / 70 \%)$ & $5: 1$ & 45 & 15 & 10 & 10 \\
\hline
\end{tabular}
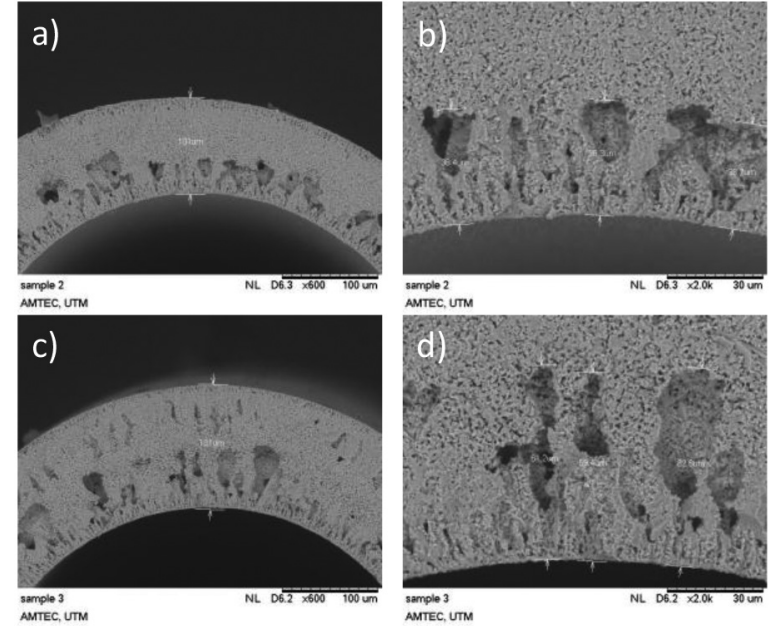

FIGURE 1. Cross-sectional images of $\mathrm{TiO}_{2}$ hollow fiber membrane prepared from $20 \mathrm{wt}$ \% ceramic suspension using single nano-size particle a) $9 \mathrm{~cm}$ air gap length, b) finger-like structture for $9 \mathrm{~cm}$ air gap length, c) $12 \mathrm{~cm}$ air gap length and d) finger-like structure for $12 \mathrm{~cm}$ air gap length 
from the lumen formed when single nano-sized particle was used in the spinning suspension even at air gap of $9 \mathrm{~cm}$. The length of finger-like structure increased when the air gap was further increased at $12 \mathrm{~cm}$. As the air gap was increased, it provided sufficient time for the phase inversion to occur from the lumen as the bore fluid was introduced into the middle of spinneret.

When the spinning process was carried out using a mixture of ceramic nano-particles, the finger-like structure vanished and replaced by a sponge-like structure, as shown in Figure 2. This finding contradicted with initial expectation that the suspension prepared from mixture of nano-sized particle should has longer finger-like structure compared with single nano-size particles. Both suspensions of 25 and $80 \mathrm{~nm}$ particles had been spun at higher air gap, which should provide more time for viscous fingering phenomenon to occur. It is expected that the ratio of ceramic to polymer plays a vital role in determining the final structure of $\mathrm{TiO}_{2}$ hollow fiber membrane. By increasing the amount of polymer in the suspension, it facilitated the viscous fingering phenomenon that led to the formation of finger-like structure. It has been known that polymer based membranes prepared using phase inversion process normally have asymmetric structure that consists of finger-like voids and sponge-like region. Based on Table 1, it can be deduced that the suspension made from mixture of 25/80 nm particles have less amount polymer compared with single nano-size suspension which caused the formation sponge-like structure through the crosssection of the membrane.

\section{MECHANICAL STRENGTH}

To study the mechanical strength of $\mathrm{TiO}_{2}$ hollow fiber membrane, the precursors prepared from both suspensions were sintered at 1200 and $1300^{\circ} \mathrm{C}$. The results in Figure 3 shows that the bending strength of $\mathrm{TiO}_{2}$ hollow fiber membrane increased when the sintering temperature was increased from 1200 to $1300^{\circ} \mathrm{C}$. This result is in agreement with the various findings that state sintering process at
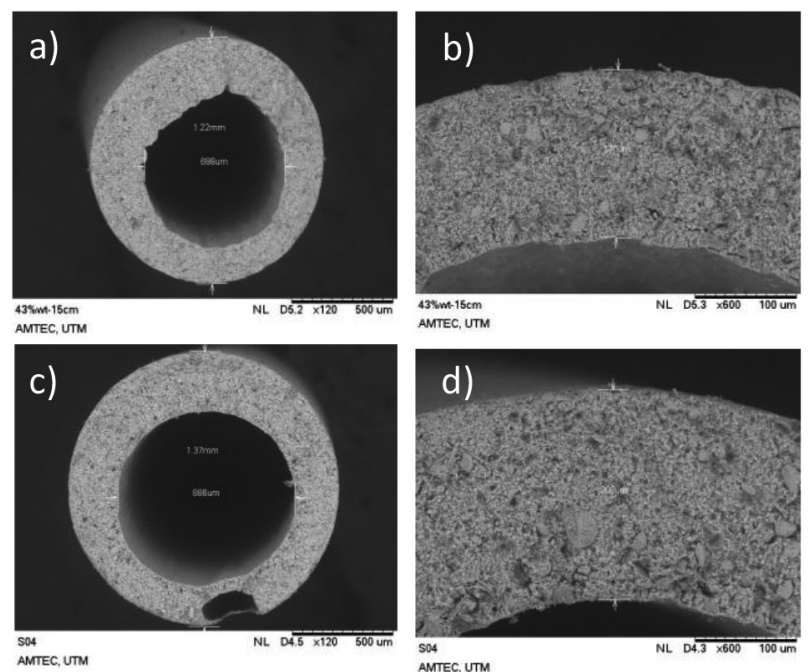

FIGURE 2. Cross-sectional images of $\mathrm{TiO}_{2}$ hollow fiber membrane prepared from ceramic suspension using mixture of nano-size particles a) 43 wt. \% ceramic loading, b) higher magnification of 43 wt. \% ceramic loading, c) 45 wt. \% ceramic loading and d) higher magnification of 45 wt. \% ceramic loading

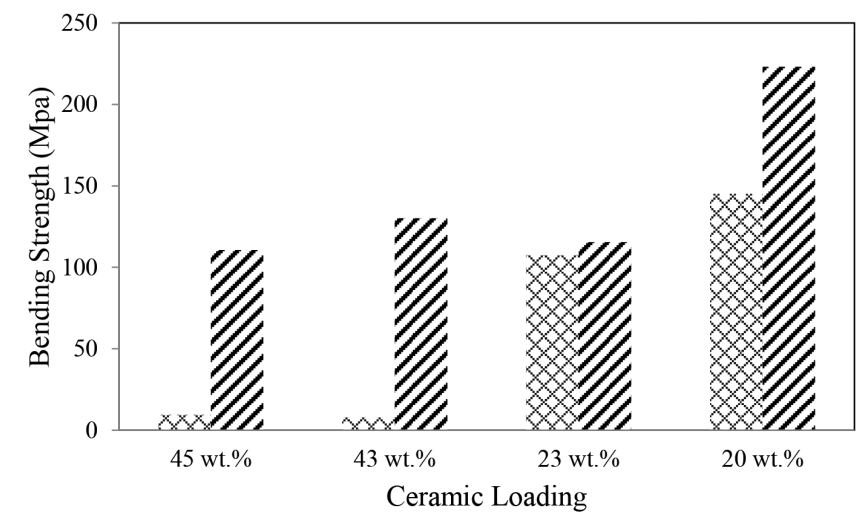

FIGURE 3. Bending strength of $\mathrm{TiO}_{2}$ hollow fiber membrane for single nano-sized and mixture nano-sized particles sintered at $\left(C_{\mathrm{x}}\right) 1200^{\circ} \mathrm{C}$ and $(\boldsymbol{*}) 1300^{\circ} \mathrm{C}$ 
elevated temperature lead to densification of ceramic particles (García-García et al. 2011; Kingsbury \& Li 2009; Othman et al. 2010a). This will enhanced the bending strength of ceramic hollow fiber membrane. The highest mechanical strength recorded in this study was $223 \mathrm{MPa}$ for $\mathrm{TiO}_{2}$ hollow fiber membrane prepared using $20 \mathrm{wt}$. \% and sintered at $1300^{\circ} \mathrm{C}$.

Further looking into the data, an improvement of mechanical strength became significant with increasing sintering temperature when the mixture of ceramic particle sizes was used. Previous studies by various authors confirm this sintering process of ceramic particles can easily occurred when different particle sizes are used during the preparation of ceramic suspension. However, $\mathrm{TiO}_{2}$ hollow fiber membrane prepared from single nano-sized particle of $25 \mathrm{~nm}$ has still higher mechanical strength compared to that of using mixture of ceramic particle sizes. It is expected that smaller nano-sized particles facilitated the sintering process of ceramic particles as it took less energy to fuse due to higher surface area.

The results from Figure 3 also showed that the bending strength increased when the ceramic loading was reduced. This happened for both type of suspensions. It is expected that the reduction in ceramic loading creates less viscous suspension, enables the milling process to be carried out smoothly. This may reduce the agglomeration of nanosized ceramic particles thus improving the uniformity of suspension.

\section{PERFORMANCE TESTS}

Gas Permeation Test $\mathrm{TiO}_{2}$ hollow fiber membranes prepared using single nano-sized particle have been used to study the permeation rate of this ceramic membrane towards an inert gas. The gas permeation tests have been chosen to study the performance of this membrane due to its morphology based on the SEM images in Figure 1. The ceramic hollow fiber membrane prepared using single nano-sized particle has finger-like structure that enables the support to be used in catalytic reactions in which catalyst can be placed in its inner surface. The advantages of this macro-structure to gas-phase catalytic reactions have been discussed in detail elsewhere (García-García et al. 2011). Figure 4 shows the permeation results of $\mathrm{TiO}_{2}$ hollow fiber membranes prepared using different ceramic loading and sintered at different sintering temperatures. These parameters were expected to influence the porosity of $\mathrm{TiO}_{2}$ hollow fiber membrane. The results suggested that $\mathrm{TiO}_{2}$ hollow fiber membranes prepared at $20 \mathrm{wt}$. \% ceramic loading have higher porosities, enabling the inert gas to pass through the membrane easily compared to that of 23 wt. \% . It is expected that $\mathrm{TiO}_{2}$ hollow fiber membrane prepared from $20 \mathrm{wt}$ \% ceramic loading has less resistance compared with 23 wt. \% due to smaller amount of ceramic used during its initial preparation. High ceramic loading can create mass resistance to gas flow which caused a reduction in gas permeation. Looking back into Figure 4 , the permeation rate has insignificant effect when the sintering temperature was increased from 1200 to $1300^{\circ} \mathrm{C}$. These data suggest that the sintering temperature can be increased up to $1300^{\circ} \mathrm{C}$ to take advantage of superior mechanical test without sacrificing the permeation rate of $\mathrm{TiO}_{2}$ hollow fiber membrane.

Pure Water Permeability Test $\mathrm{TiO}_{2}$ hollow fiber membrane prepared using mixture of nano-size particles have been used in water permeability test. The results from Figure 5(a) shows that the membrane prepared at $43 \mathrm{wt}$. \% loading has higher pure water permeability compared to $45 \mathrm{wt}$. $\%$. An increase in ceramic loading caused a reduction in the water permeability of $\mathrm{TiO}_{2}$ hollow fiber membrane. Similar to gas permeation results, $43 \mathrm{wt}$. \% ceramic loading creates less mass resistance compared to $45 \mathrm{wt} \%$. As the pressure of the permeation side was increased from 1 to 2 bar, both samples showed an improvement in the pure water permeability. This finding can be expected because an increase in system pressure leads to more water to pass

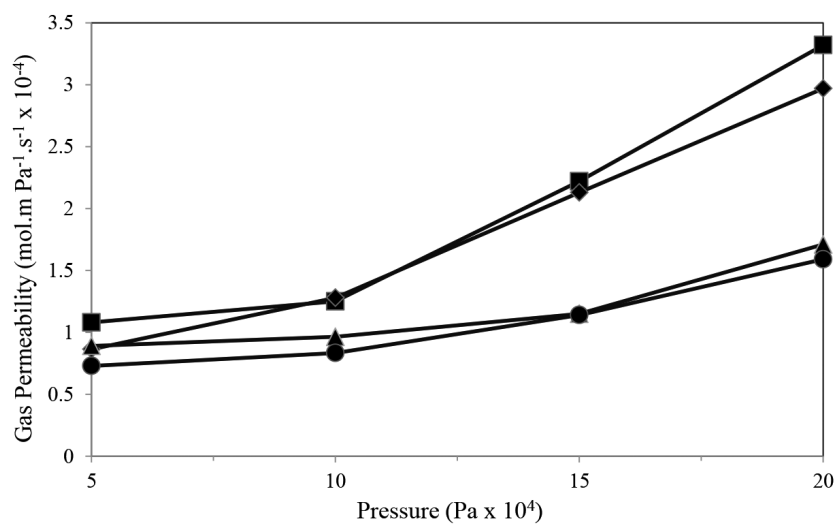

FIGURE 4. Gas permeability of $\mathrm{TiO}_{2}$ hollow fiber membrane at different ceramic loading and sintering temperature ( $\bullet$ ) $20 \mathrm{wt}$. \% ceramic loading sintered at $1200^{\circ} \mathrm{C}$, ( $\left.\bullet\right) 20 \mathrm{wt}$. $\%$ ceramic loading sintered at $1300^{\circ} \mathrm{C},(\boldsymbol{\Delta}) 23 \mathrm{wt}$. \% ceramic loading sintered at $1200^{\circ} \mathrm{C}$ and $(\bullet) 23$ wt. $\%$ ceramic loading sintered at $1300^{\circ} \mathrm{C}$ 


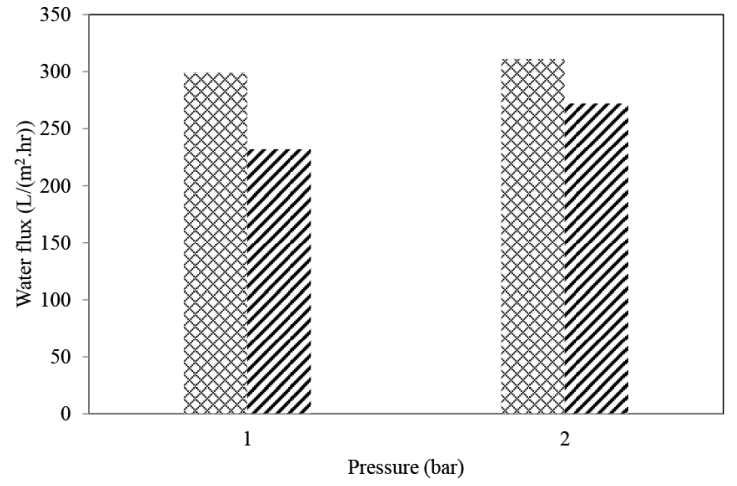

(a)

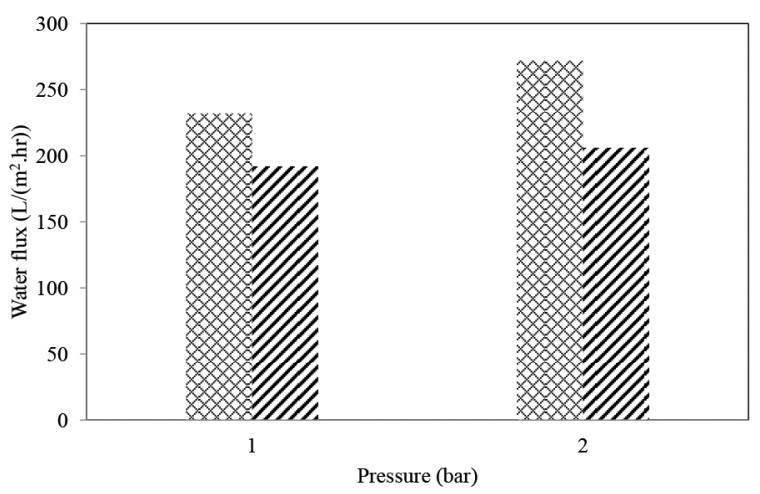

(b)

FIGURE 5. a) Water permeation data of $\mathrm{TiO}_{2}$ hollow fiber membrane prepared using a mixture nano-size particles at ceramic loading of () $43 \mathrm{wt}$. \% and () $45 \mathrm{wt} . \%$ and b) Water permeation data of $\mathrm{TiO}_{2}$ hollow fiber membrane prepared using a mixture nano-size particles sintered at $\left(C_{\mathrm{x}}\right) 1200^{\circ} \mathrm{C}$ and $\left(\boldsymbol{F}_{\boldsymbol{L}}\right) 1300^{\circ} \mathrm{C}$

through the cross-section of the membrane. The data in Figure 5(a) suggests that both samples have considerably high water permeability, although the cross-section of the membrane is dense and has a symmetric structure. This was due to $\mathrm{TiO}_{2}$ itself was a ceramic material that has hydrophilic property that enables pure water to permeate via its cross-section easily. The permeability of pure water was affected by the sintering temperature of the ceramic membrane as shown in Figure 5(b). Both samples show a reduction in the amount of water collected during permeation test when the sintering temperature was increased from 1200 to $1300^{\circ} \mathrm{C}$. Sintering process led to particle densification which causes micro-pores to be eliminated, increasing mass resistance across the membrane.

\section{CONCLUSION}

$\mathrm{TiO}_{2}$ hollow fiber membranes were successfully prepared using the phase inversion and sintering technique. Using single nano-sized and mixture nano-sized particles, the suitable ratio of ceramic to polymeric were determined to find acceptable range of spinnability. Different ceramic loadings obtained based on formulation used in this study. $\mathrm{TiO}_{2}$ hollow fiber membranes prepared from single nanosized particles has an asymmetric structure and mixture nano-sized particles produced dense symmetric structure. The mechanical strengths of $\mathrm{TiO}_{2}$ hollow fiber membranes were influenced by sintering temperature, particles size and ceramic loading. The highest mechanical strength recorded in this study was $223 \mathrm{MPa}$ for hollow fiber membrane prepared using $20 \mathrm{wt} . \%$ and sintered at $1300^{\circ} \mathrm{C}$. Both types of suspensions were used to make membrane for gas and water separation. Low ceramic loading gave better performance for both gas permeation and pure water flux. Sintering temperature affected the pure water flux but gave insignificant effect to gas permeation through the hollow fiber membrane.

\section{ACKNOWLEDGEMENTS}

The authors gratefully acknowledge the financial support from the Ministry of Science, Technology and Innovation Malaysia (MOSTI), Malaysia under Sciencefund program (Project Number: R.J130000.7942.4S031) and Universiti Teknologi Malaysia under Research University Grant (Project Number: Q.J130000.2542.03H15 and Q.J130000.2509.05H68). The authors also acknowledged the technical and management support from the Research Management Centre, Universiti Teknologi Malaysia.

\section{REFERENCES}

García-García, F.R., Rahman, M.A., Kingsbury, B.F.K. \& Li, K. 2011. Asymmetric ceramic hollow fibres: New microsupports for gas-phase catalytic reactions. Applied Catalysis A: General 393: 71-77.

Kingsbury, B.F.K. \& Li, K. 2009. A morphological study of ceramic hollow fibre membranes. Journal of Membrane Science 328: 134-140.

Koros, W.J., Coleman, M.R. \& Walker, D.R.B. 1992. Controlled permeability polymer membranes. Annual Review of Materials Science 22: 47-89.

Lange, R.S.A., Hekkink, J.H.A., Keizer, K. \& Burggraaf, A.J. 1995. Formation and characterization of supported microporous ceramic membranes prepared by sol-gel modification techniques. Journal of Membrane Science 99: $57-75$.

Liu, S., Tan, X., Li, K. \& Hughes, R. 2001. Preparation and characterization of $\mathrm{SrCe}_{0.95} \mathrm{Yb}_{0.05} \mathrm{O}_{2.975}$ hollow fibre membranes. Journal of Membrane Science 193: 249-260.

Othman, M.H.D., Wu, Z., Droushiotis, N., Doraswami, U., Kelsall, G. \& Li, K. 2010a. Single-step fabrication and characterisations of electrolyte/anode dual-layer hollow fibres for micro-tubular solid oxide fuel cells. Journal of Membrane Science 351: 196-204.

Othman, M.H.D., Wu, Z., Droushiotis, N., Kelsall, G. \& Li, K. 2010b. Morphological studies of macrostructure of Ni-CGO anode hollow fibres for intermediate temperature solid oxide fuel cells. Journal of Membrane Science 360: 410-417.

Shao, P. \& Huang, R.Y.M. 2007. Polymeric membrane pervaporation. Journal of Membrane Science 287: 162-179. 
Ulbricht, M. 2006. Advanced functional polymer membranes. Polymer 47: 2217-2262.

Wei, C.C., Chen, O.Y., Liu, Y. \& Li, K. 2008. Ceramic asymmetric hollow fibre membranes - One step fabrication process. Journal of Membrane Science 320: 191-197.

Wu, Z.T., Thursfield, A., Metcalfe, I. \& Li, K. 2012. Effects of separation layer thickness on oxygen permeation and mechanical strength of DL-HFMR-ScSZ. Journal of Membrane Science 415: 229-236.

Zaidi, S.M.J. 2003. Polymer sulfonation - A versatile route to prepare proton-conducting membrane material for advanced technologies. Arabian Journal for Science and Engineering 28: $183-194$.

Advanced Membrane Technology Research Centre Faculty of Petroleum and Renewable Energy Engineering Universiti Teknologi Malaysia

81310 Skudai, Johor Darul Takzim

Malaysia
*Corresponding author; email: r-mukhlis@utm.my

Received: 16 July 2014

Accepted: 6 April 2015 